\title{
ASSESSMENT OF KNOWLEDGE AND AWARENESS REGARDING IMMUNIZATION AMONG THE MOTHERS OF UNDER FIVE CHILDREN ATTENDING IMMUNIZATION CLINIC OF A TERTIARY CARE HOSPITAL
}

\author{
Subodh Mishra1 ${ }^{1}$ Akshat Pathak2, Monoj Bansal ${ }^{3}$ \\ ${ }^{1}$ Associate Professor, Deputy Director of Medical Education Department, Department of Community Medicine, Govt. of M. P. Satpuda \\ Bhavan, Bhopal, Madhya Pradesh. \\ ${ }^{2}$ Demonstrator, Post Graduate Student, Department of Community Medicine, L. N. Medical College, Bhopal, Madhya Pradesh. \\ ${ }^{3}$ Assistant Professor, Department of Community Medicine, G. R. Medical College, Gwalior, Madhya Pradesh.
}

\section{ABSTRACT}

\section{BACKGROUND}

Immunization is one of the most powerful and cost-effective weapons of modern medicine. In 2012, nearly 22.6 million children missed out of the basic vaccines they need to stay healthy. Low immunization levels compromise gains in all other areas of health for mothers and children.

\section{MATERIAL AND METHOD}

A cross-sectional descriptive study carried out among the mothers of under-five children attending immunization clinic using a predesigned and pre-tested structured proforma. Non-probability sampling method was used in the study. Study duration was 03 months from October 2014 to December 2014.

\section{RESULTS}

A total of 230 mothers of under-five children in the age group of 20 to 45 years were interviewed. Among these, nearly two third $(67.83 \%)$ were in age group of 20-29 years. Awareness about polio vaccination was $100 \%$ while knowledge about Measles vaccination was found $83 \%$. Most common source of information was health workers.

\section{CONCLUSION}

Mother's knowledge regarding immunization is essential for timely utilization of immunization services as it is the most cost effective measure to prevent vaccine preventable diseases. Health workers mainly contributed to enhance mother's knowledge regarding immunization.

\section{KEYWORDS}

Knowledge, Immunization, Under-five.

HOW TO CITE THIS ARTICLE: Mishra S, Pathak A, Bansal M. Assessment of knowledge and awareness regarding immunization among the mothers of under five children attending immunization clinic of a tertiary care hospital. J Evolution Med Dent Sci 2016;5(2):103-105, DOI: 10.14260/jemds/2016/24

\section{INTRODUCTION}

One effective way of controlling the spread of infection is to strengthen the host defences. Under certain circumstances this may be accomplished by active immunization, which is one of the most powerful and cost-effective weapons of modern medicine. Immunization has to be planned according to the needs of the situation. ${ }^{1}$

The historical success of eradicating the dreaded disease, Smallpox, prompted World Health Organization (WHO) to ask its member countries to launch immunization against six vaccine preventable diseases in its national immunization schedule. In May 1974, the WHO launched the Expanded Immunization Programme (EPI) globally, with focus on prevention of 6 vaccine-preventable diseases by the year 2000 . In India, EPI was launched in 1978 and it was re-designated as the Universal Immunization Programme (UIP) in 1985, with a goal to cover at least $85 \%$ of infants. ${ }^{1}$

Financial or Other, Competing Interest: None.

Submission 26-12-2015, Peer Review 27-12-2015,

Acceptance 01-01-2016, Published 05-01-2016.

Corresponding Author:

Dr. Subodh Mishra,

306, Kashi Mansion Building,

Lalitpur Colony,

Gwalior-474001,

Madhya Pradesh.

E-mail:drsubodhmishragwalior@gmail.com

DOI:10.14260/jemds/2016/24
Vaccines are protecting more children than ever before. But, in 2012, nearly one in five infants-22.6 million childrenmissed out on the basic vaccines they need to stay healthy. Low immunization levels compromise gains in all other areas of health for mothers and children.

The poorest, most vulnerable children who need immunization the most continue to be the least likely to get it. ${ }^{2}$ National Family Health Survey (2005-06) reports that only $43.5 \%$ of children in India received all of their primary vaccines by 12 months of age. ${ }^{3}$ Therefore, this study was done to know the mother's awareness on vaccine preventable diseases and vaccines given under UIP.

\section{MATERIAL AND METHOD}

The present study is a cross-sectional descriptive study carried out for the duration of 3 months from October to December 2014. All the mothers of under-five children attending immunization clinic of J.A. Group of Hospitals, Gwalior (MP) on Wednesday, the immunization day, were included as study participants.

A predesigned and pre-tested structured questionnaire was used to collect the desired information from study participants regarding socio-demographic profile, knowledge about vaccine preventable diseases, immunization and source of information. 
After the collection of required information from the respondents data was compiled and analysed manually using percentage and proportions.

\section{Inclusion Criteria}

Mothers who gave verbal consent to participate in the study.

\section{Exclusion Criteria}

Mothers who refused to participate in the study.

\section{Ethical Consideration}

The study did not require any invasive or non-invasive diagnostic procedure, or withholding any prescribed drug; yet prior permission of competent authority was obtained for conducting study.

\section{RESULTS}

A total of 230 mothers of under-five children in the age group of 20 to 45 years were interviewed. Among these, nearly two third $(67.83 \%)$ were in age group of 20-29 years.

Majority of the participants were educated up to higher secondary $(58.26 \%)$ and $87.83 \%$ of the respondents were housewives. (Table 1) Out of total 230 respondents about 95\% heard about vaccine preventable diseases.

All the study participants were aware about polio vaccination while knowledge about Measles vaccination was found $83 \%$. Regarding the source of information about immunization most common were health workers including ASHA workers, Anganwadi workers and ANMs followed by television. (Table 2).

\section{DISCUSSION}

In the present study a total of 230 mothers attending immunization clinic in the age group of 20 to 45 years were interviewed. Among these, nearly two-third (67.83\%) were in age group of 20-29 years and majority of the participants (87.83) were housewives.

While $72 \%$ of study participants were housewives in a study done by Rachna Kapoor, et al. in Ahmedabad. ${ }^{4}$ In this study majority of the study participants were Hindus $72.6 \%$, while Mereena et al. in their study reported that majority of the respondents were Muslims. ${ }^{5}$

In our study, all the study participants (100\%) were aware about polio vaccination while knowledge about Measles vaccination was found $83 \%$. While Rachna Kapoor et al. in 2010 reported that $85 \%$ of mothers were aware about polio vaccination. ${ }^{4}$ The rise in knowledge level may be because of increasing awareness and greater IEC activities.

The present study revealed that $53.48 \%$ mothers had knowledge about TB vaccination. Similar finding was reported by Rahul Sharma et al. ${ }^{6}$

Regarding the source of information about immunization most common were health workers including ASHA workers, Anganwadi workers and ANMs followed by television while in the study conducted by D. Adeyinka et al. Four $65.7 \%$ of the respondents got information about Vaccine Preventable Diseases from Antenatal clinics and role of media was only $4.8 \% .^{7}$

\section{CONCLUSION}

Mother's knowledge regarding immunization is essential for timely utilization of immunization services as it is the most cost effective measure to prevent vaccine preventable diseases.
Health workers should organize regular mother's meeting in the community and take the opportunity to enhance their knowledge on immunization and to remove fear and misconceptions about vaccines.

\begin{tabular}{|c|c|c|}
\hline $\begin{array}{l}\text { Sl. } \\
\text { No. }\end{array}$ & Variable & $\begin{array}{l}\text { Respondents } \\
(\mathrm{N}=230)(\%)\end{array}$ \\
\hline 1. & $\begin{array}{c}\text { Age (Years) } \\
20-29 \\
30-39 \\
40 \text { and above }\end{array}$ & $\begin{array}{c}156(67.83) \\
63(27.39) \\
11(4.78) \\
\end{array}$ \\
\hline 2. & $\begin{array}{l}\text { Religion } \\
\text { Hindu } \\
\text { Muslim } \\
\text { Others } \\
\end{array}$ & $\begin{array}{c}167(72.60) \\
58(25.21) \\
05(2.17)\end{array}$ \\
\hline 3. & $\begin{array}{c}\text { Caste } \\
\text { General } \\
\text { Schedule Caste } \\
\text { Schedule Tribe } \\
\text { Other Backward Castes }\end{array}$ & $\begin{array}{l}93(40.43) \\
59(25.65) \\
27(11.74) \\
51(22.17)\end{array}$ \\
\hline 4. & $\begin{array}{c}\text { Education } \\
\text { Illiterate } \\
\text { Primary } \\
\text { High School } \\
\text { Higher Secondary } \\
\text { Graduate and above } \\
\end{array}$ & $\begin{array}{l}17(7.39) \\
19(8.26) \\
48(20.87) \\
67(29.13) \\
68(29.56) \\
\end{array}$ \\
\hline 5. & $\begin{array}{l}\text { Occupation } \\
\text { House wife } \\
\text { Self employed } \\
\text { Government job } \\
\text { Private job } \\
\end{array}$ & $\begin{array}{c}202(87.83) \\
17(7.39) \\
03(1.30) \\
08(3.48) \\
\end{array}$ \\
\hline
\end{tabular}

\begin{tabular}{|c|c|c|c|}
\hline \multirow{2}{*}{$\begin{array}{l}\text { Sl. } \\
\text { No. }\end{array}$} & \multirow{2}{*}{$\begin{array}{c}\text { Knowledge } \\
\text { Variables }\end{array}$} & \multicolumn{2}{|c|}{ Response } \\
\hline & & Yes (\%) & No (\%) \\
\hline 1. & $\begin{array}{l}\text { Have you ever heard } \\
\text { about vaccine } \\
\text { preventable diseases }\end{array}$ & 219 (95.21) & $11(4.78)$ \\
\hline 2. & $\begin{array}{l}\text { Knowledge about } \\
\text { vaccines for } \\
\text { Tuberculosis } \\
\text { Poliomyelitis } \\
\text { Diphtheria } \\
\text { Pertussis } \\
\text { Hepatitis B } \\
\text { H. influenzae } \\
\text { Measles } \\
\text { Tetanus }\end{array}$ & $\begin{array}{c}123(53.48) \\
230(100) \\
67(29.13) \\
55(23.91) \\
138(60.00) \\
35(15.22) \\
191(83.04) \\
214(93.04)\end{array}$ & $\begin{array}{c}107(46.52) \\
00(00.00) \\
163(70.87) \\
175(76.08) \\
92(40.00) \\
195(84.78) \\
39(16.96) \\
16(6.96)\end{array}$ \\
\hline 3. & $\begin{array}{c}\text { Source of knowledge } \\
\text { Health workers } \\
\text { (ASHA*/AWW**/ANM*** } \\
\text { etc.) } \\
\text { Television } \\
\text { Radio } \\
\text { Newspaper } \\
\text { Neighbours } \\
\text { Family members } \\
\text { Banners/Posters } \\
\text { Others }\end{array}$ & $\begin{array}{c}212(92.17) \\
173(75.21) \\
81(35.21) \\
130(56.52) \\
144(62.61) \\
165(71.74) \\
88(38.26) \\
37(16.08)\end{array}$ & $\begin{array}{c}18(7.82) \\
57(24.78) \\
149(64.78) \\
100(43.48) \\
86(37.39) \\
65(28.26) \\
142(61.74) \\
193(83.91)\end{array}$ \\
\hline & $\begin{array}{r}\text { Table 2: Knowled } \\
\text { about Imn }\end{array}$ & $\begin{array}{l}\text { respond } \\
\text { zation }\end{array}$ & \\
\hline
\end{tabular}

${ }^{*}$ Accredited Social Health Activist **Anganwadi worker *** Auxiliary Nurse Midwife 


\section{REFERENCES}

1. Park's Textbook of Preventive and Social Medicine. Bhanot Publication, Jabalpur, 22 ${ }^{\text {nd }}$ edition; p113-114. URLhttp://www.unicef.org/immunization/index_2819. html. Accessed on 20 th Dec.2015.

2. Immunization Handbook for Medical Officers; Dept. of Health \& Family Welfare, Govt. of India; p10, 15.

3. Rachna Kapoor, Vyas Sheetal. "Awareness and knowledge of mothers of under-five children regarding immunization in Ahmedabad." The Journal of Preventive and Social Medicine Gujarat Chapter. Volume I. Issue 1. JulyDecember 2010, p: 1215.
4. Mereena, Sujatha R. A study on knowledge and attitude regarding vaccines among mothers of under five children attending pediatric OPD in a selected hospital at Mangalore. IOSR Journal of Nursing and Health Science. Volume 3, Issue 5 Ver. III (Sep.-Oct. 2014), PP 39-46.

5. Rahul Sharma \& Sanjiv K Bhasin. Routine ImmunizationDo People Know About It? A study among caretakers of children attending pulse polio immunization in East Delhi. Indian Journal of Community Medicine. 2008 January;33 (1):31-34.

6. Adeyinka D, et al. Uptake of childhood immunization among mothers of under five in South Western Nigeria. The Internet Journal of Epidemiology, 2009; 7; Number 2. 